\title{
Vibrio aerogenes sp. nov., a facultatively anaerobic marine bacterium that ferments glucose with gas production
}

\author{
Wung Yang Shieh, Aeen-Lin Chent and Hsiu-Hui Chiu
}

Institute of Oceanography, National Taiwan University, PO Box 23-13, Taipei, Taiwan
Author for correspondence: Wung Yang Shieh. Tel. +886223636040 ext. 417 Fax: +886223626092. e-mail: winyang@ms.cc.ntu.edu.tw

Keywords: Vibrio aerogenes sp. nov., marine bacterium, facultative anaerobe

\section{INTRODUCTION}

Bacteria inhabiting the marine environment include halophiles and non-halophiles. Only the halophiles are considered to be autochthonous organisms, i.e. true marine bacteria. The non-halophilic ones tolerate the salinity of seawater but are not considered to be of marine origin since they do not require $\mathrm{Na}^{+}$for growth and are always found in a non-saline environment. Most halophilic marine bacteria are either mesophilic or psychrophilic Gram-negative rods that require 70-700 $\mathrm{mM} \mathrm{Na}^{+}$for optimal growth and yield in laboratory media (Baumann \& Baumann, 1971). A large proportion of these bacteria are facultative anaerobes that can ferment glucose and other carbohydrates for anaerobic growth. Marine bacteria of this type are currently placed in the genera Vibrio

† Present address: Culture Collection and Research Center, Food Industry Research and Development Institute, PO Box 246, Hsinchu, Taiwan.

Abbreviations: MOPSO, 3-( $N$-morpholino)-2-hydroxysulfonic acid; PHB, poly- $\beta$-hydroxybutyrate.

The GenBank accession number for the $16 \mathrm{~S}$ rDNA sequence of strain FG ${ }^{\top}$ is AF124005.
(Baumann et al., 1984), Photobacterium (Baumann \& Baumann, 1984), Listonella (MacDonell \& Colwell, 1985) and Colwellia (Deming et al., 1988) of the family Vibrionaceae (Baumann \& Schubert, 1984). These bacteria generally constitute $10-50 \%$ of heterotrophic bacteria from coastal and oceanic seawater samples that grow on ordinary plate media used in marine bacteriology (Simidu \& Tsukamoto, 1985). They are also found to be closely associated with many kinds of marine organisms from plankton to fish (CerdàCuéllar et al., 1997; Liston, 1956; MacDonald et al., 1986; Nair et al., 1988; Onarheim et al., 1994; Simidu et al., 1969, 1971; Sochard et al., 1979; Yoshimizu et al., 1976). Some species are found as symbionts in specialized luminous organs of marine fish and invertebrates (Lee \& Ruby, 1994; Leisman et al., 1980; McFall-Ngai \& Ruby, 1991; Reichelt et al., 1977; Ruby \& Asato, 1993; Ruby \& Morin, 1978), whereas quite a few other species are well-known pathogens for humans or marine animals (Blake et al., 1980; Egidus et al., 1986; Hada et al., 1984; Holt et al., 1994; Love et al., 1981; Schiewe et al., 1981). These halophilic, facultatively anaerobic, Gram-negative rods are presently known to include both nitrogen fixers and 
denitrifiers (Guerinot \& Colwell, 1985; Guerinot et al., 1982; Shieh \& Lin, 1992, 1994; Shieh \& Liu, 1996; Shieh \& Yang, 1997; Shieh et al., 1989, 1990; West et al., 1985), although Bergey's Manual of Systematic Bacteriology defined in 1984 that they include neither of the two (Baumann \& Baumann, 1984; Baumann \& Schubert, 1984; Baumann et al., 1984).

Production of gas during glucose fermentation is a characteristic commonly found among the non-halophilic, facultatively anaerobic, Gram-negative rods belonging to either Enterobacteriaceae (Brenner, 1984) or Aeromonadaceae (Colwell et al., 1986). It is, therefore, intriguing why the halophilic, facultatively anaerobic, Gram-negative rods that also possess this property are not prevalent. Vibrio gazogenes, Vibrio furnissii (formerly Vibrio fluvialis biovar 2), Vibrio mytili, Photobacterium histaminum, Photobacterium iliopiscarium, Photobacterium phosphoreum and Listonella damsela (reclassified as Photobacterium damselae subsp. damselae) are the only cases among the more than forty validly described species of these bacteria that produce gas during the fermentation of glucose (Baumann \& Baumann, 1984; Baumann \& Schubert, 1984; Baumann et al., 1984; Brenner et al., 1983; Holt et al., 1994; Okuzumi et al., 1994; Onarheim et al., 1994; Pujalte et al., 1993; Urakawa et al., 1999).

A new strain of halophilic, facultatively anaerobic, Gram-negative rod has been recovered in this laboratory from a sediment sample collected in a seagrass bed in Nanwan Bay, Kenting National Park, Taiwan. The present study shows that the new strain can achieve anaerobic growth by fermenting glucose and other carbohydrates with the production of various organic acids and $\mathrm{H}_{2}$ and $\mathrm{CO}_{2}$. Evidence presented in the study also shows that the strain represents a new species of Vibrio, for which the name Vibrio aerogenes is proposed.

\section{METHODS}

Culture media. Polypeptone-yeast (PY) broth contained the following ingredients $\left(1^{-1}\right.$ deionized water): $3 \mathrm{~g}$ Polypepton (Nihon Seiyaku); $1 \mathrm{~g}$ Bacto yeast extract (Difco); $25 \mathrm{~g}$ $\mathrm{NaCl}$; and $5 \mathrm{~g} \mathrm{MgCl}_{2} \cdot 6 \mathrm{H}_{2} \mathrm{O}$. The medium was adjusted to $\mathrm{pH} 7 \cdot 8$. Bacto agar (Difco) was added to this medium at $3 \cdot 5$ and $15 \mathrm{~g} \mathrm{l}^{-1}$, for the preparation of stab and plate media, respectively. Polypepton-yeast-nitrate (PYN) broth was prepared by adding $\mathrm{KNO}_{3}$ at $0 \cdot 1 \mathrm{~g} \mathrm{l}^{-1}$ to $\mathrm{PY}$ broth. Tryptone broth contained $10 \mathrm{~g}$ tryptone (Sigma), $25 \mathrm{~g} \mathrm{NaCl}$ and $5 \mathrm{~g}$ $\mathrm{MgCl}_{2} \cdot 6 \mathrm{H}_{2} \mathrm{O}$ dissolved in $1000 \mathrm{ml}$ deionized water and adjusted to $\mathrm{pH} 7 \cdot 8$. Polypepton-yeast-carbohydrate (PYC) stab media were prepared from two parts. The first contained $3 \mathrm{~g}$ polypeptone, $1 \mathrm{~g}$ Bacto yeast extract, $25 \mathrm{~g}$ $\mathrm{NaCl}, 5 \mathrm{~g} \mathrm{MgCl}_{2} .6 \mathrm{H}_{2} \mathrm{O}, 0 \cdot 24 \mathrm{~g}$ Tris (Sigma), $0.03 \mathrm{~g}$ bromothymol blue and $10 \mathrm{~g}$ Bacto agar dissolved in $900 \mathrm{ml}$ deionized water and adjusted to $\mathrm{pH} \mathrm{7.8.} \mathrm{The} \mathrm{second} \mathrm{con-}$ tained $5 \mathrm{~g}$ glucose (or any carbohydrate) dissolved in $100 \mathrm{ml}$ deionized water. The two parts were autoclaved separately and mixed at about $50^{\circ} \mathrm{C}$. Glucose-mineral (GM) medium was also made up of two parts. Part 1 contained $0.54 \mathrm{~g} \mathrm{NH}_{4} \mathrm{Cl}, 25 \mathrm{~g} \mathrm{NaCl}^{2}, 2 \mathrm{~g} \mathrm{MgCl}_{2} \cdot 6 \mathrm{H}_{2} \mathrm{O}, 3 \mathrm{~g} \mathrm{~K}_{2} \mathrm{SO}_{4}, 0.2 \mathrm{~g}$
$\mathrm{K}_{2} \mathrm{HPO}_{4}, 0.01 \mathrm{~g} \mathrm{CaCl}_{2}, 0.005 \mathrm{~g} \mathrm{FeCl}_{3} .6 \mathrm{H}_{2} \mathrm{O}$ and $3 \mathrm{~g}$ (ca. 25 $\mathrm{mmol}$ ) Tris dissolved in $900 \mathrm{ml}$ deionized water and adjusted to $\mathrm{pH} 8 \cdot 0$, while part 2 contained $5 \mathrm{~g}$ glucose dissolved in $100 \mathrm{ml}$ deionized water. The two parts were autoclaved separately and mixed at room temperature. However, GMII medium differed from GM medium in that part 1 contained $5.4 \mathrm{~g} \mathrm{l}^{-1}$ (ca. $\left.25 \mathrm{mM}\right) 3$-( $N$-morpholino)-2-hydroxysulfonic acid (MOPSO; Sigma) instead of Tris and was adjusted to $\mathrm{pH} 7 \cdot 0$.

A modified PY plate medium containing $\mathrm{CaCl}_{2}\left(0 \cdot 1 \mathrm{~g} \mathrm{l}^{-1}\right)$ and Tween $80(0 \cdot 1 \%)$ was used for the lipase test. Four other modified PY plate media containing casein $\left(4 \mathrm{~g}^{-1}\right)$, DNA $\left(2 \mathrm{~g} \mathrm{l}^{-1}\right)$, gelatin $\left(5 \mathrm{~g} \mathrm{l}^{-1}\right)$ and starch $\left(5 \mathrm{~g}^{-1}\right)$, respectively, were also used to test the hydrolysis of these substrates. In addition, three stab media modified from Thornley's semisolid arginine medium (Smibert \& Krieg, 1994) were used for the tests of arginine dihydrolase, and lysine and ornithine decarboxylases. They contained the following ingredients $\left(\mathrm{l}^{-1}\right.$ deionized water): $2 \mathrm{~g}$ Bacto peptone (Difco); $25 \mathrm{~g}$ $\mathrm{NaCl} ; 5 \mathrm{~g} \mathrm{MgCl}_{2} .6 \mathrm{H}_{2} \mathrm{O}$; $0.01 \mathrm{~g}$ phenol red; $3 \mathrm{~g}$ Bacto agar (Difco); and $5 \mathrm{~g}$ L-arginine, $5 \mathrm{~g}$ L-lysine or $5 \mathrm{~g}$ L-ornithine. All three media were adjusted to $\mathrm{pH} 7 \cdot 0$. All the $\mathrm{pH}$ adjustments of the above-mentioned media were made with $\mathrm{HCl}(1 \cdot 0 \mathrm{M}), \mathrm{KOH}(1 \cdot 0 \mathrm{M})$ or both.

Bacterial isolation. Nanwan Bay of Kenting National Park is located on the south coast of Taiwan, where fringing reefs are widely distributed. Thalassia hemprichii and Halodule uninervis are two seagrass species found to co-habit in a seagrass bed of this bay. Non-rhizosphere sediment samples were collected from the seagrass bed in the morning at low tide. Some wet mass ( $2 \mathrm{~g})$ of each sediment sample was vigorously shaken in sterile $\mathrm{NaCl}$-Tris buffer $(30 \mathrm{~g} \mathrm{NaCl}$ and $0.24 \mathrm{~g}$ Tris in 11 deionized water, $\mathrm{pH} 8.0$ ) containing Tween 80 (2 p.p.m.), and the shaken solutions were decimally diluted with the same buffer. A volume $(1 \mathrm{ml})$ of each dilution $\left(10^{5}-10^{7}\right.$ times) was transferred to a rimless tube $(16 \mathrm{~mm} \times 10 \mathrm{~cm})$ containing GM medium $(5 \mathrm{ml})$ in which an inverted Durham insert had been placed. All culture tubes were set in anaerobic jars (Difco) and incubated at $25^{\circ} \mathrm{C}$ in the dark for $7 \mathrm{~d}$. The air in each anaerobic jar was replaced by $\mathrm{Ar}$ before incubation. Those cultures that developed visible turbidity and produced gas (accumulated in Durham inserts) were streaked (one loopful) on PY plate medium and the plates were incubated at $25^{\circ} \mathrm{C}$ in the dark for $2-3 \mathrm{~d}$ under air. Individual colonies appearing on the plates were picked off and purified by successive streaking on PY plates. One bacterial strain, capable of growth with gas production in GM medium under Ar, was isolated for the present study using the above-mentioned procedures. This bacterium was designated as strain $\mathrm{FG}^{\mathrm{T}}$ and its PY stab cultures were kept at $20^{\circ} \mathrm{C}$ under aerobic conditions for maintenance.

Bacterial growth. Inoculum cultures of strain $F G 1^{\mathrm{T}}$ were routinely grown in PY broth. Late exponential to early stationary phase cultures (one loopful) were inoculated into tubes containing $5 \mathrm{ml}$ of the test media to determine the effects of various factors on growth. The cultures were statically incubated under either aerobic or anaerobic conditions. Anaerobic conditions were developed by flushing the culture tubes for more than 5 min with Ar gas of $99.99 \%$ purity. The tubes were sealed with rubber stoppers that were pierced with two hypodermic needles; one needle was connected to the pipeline of Ar gas for flushing while the other was used for exhausting. Each tube was shaken vigorously on a mixer during the flushing process, after which the needles were pulled out of the stoppers. The $\mathrm{OD}_{600}$ of each culture was measured using a Spectronic 20 
spectrophotometer (Milton Roy Company). The measurement was taken every $12-24 \mathrm{~h}$ until the maximal $\mathrm{OD}_{600}$ of each culture was passed. Specific growth rates were calculated from changes in the $\mathrm{OD}_{600}$ of the cultures during the exponential phase of growth. All growth experiments were performed at $30^{\circ} \mathrm{C}$ in the dark unless otherwise stated. All the results presented here represent means of at least three replicates.

Bacterial characterization. Cells grown for 2-3 d on PY plate medium were used for agarase, luminescence, catalase, oxidase and swarming tests according to the procedures of Shieh et al. (1989). Gram reaction was determined by staining (Smibert \& Krieg, 1994) and by the KOH lysis method (Buck, 1982). Cells grown for $1-3 \mathrm{~d}$ in GM-II medium were used for the test of poly- $\beta$-hydroxybutyrate (PHB) accumulation by a staining method (Smibert \& Krieg, 1994). Caseinase, DNase, gelatinase and lipase tests essentially followed the methods of Smibert \& Krieg (1994). Indole production was determined by Kovacs' method (Smibert \& Krieg, 1994) after incubating the tryptone broth cultures for 2-3 d. Cultures grown in PYN broth were examined daily for nitrate reduction (Collins et al., 1995) and denitrification (Shieh et al., 1997) for up to $5 \mathrm{~d}$. Sensitivity to the vibriostatic agent O/129 phosphate was tested by a disc-sensitivity method on PY plates. Any inhibition zones around the discs were read as sensitive (Baumann et al., 1984). Cells grown for $2 \mathrm{~d}$ in PY broth and GM-II medium were observed for their shape and motility by phase-contrast microscopy, and fixed with glutaraldehyde $(3 \%, \mathrm{v} / \mathrm{v})$ and negatively stained with potassium phosphotungstate $(1 \%, \mathrm{w} / \mathrm{v} ; \mathrm{pH} 7 \cdot 0)$ for transmission electron microscopy.

Cells grown on PY plate medium were taken with a straight needle for inoculation into each of the PYC stab media for tests of acid production from fermentation of various carbohydrates. The surface of the medium in each tube was overlaid with sterile liquid paraffin after inoculation. The cultures were examined daily for colour changes for $7 \mathrm{~d}$. Gas production was indicated by formation of gas bubbles or cracks in the medium, or by the separation of medium from the side or bottom of the tube. The cultures for tests of arginine dihydrolase and lysine and ornithine decarboxylases were also incubated under anaerobic conditions by overlaying the surface of the medium in each tube with sterile liquid paraffin after inoculation. A positive reaction was indicated by a colour change of the culture from yelloworange to red within $7 \mathrm{~d}$ due to an increase in the $\mathrm{pH}$ value. The ability to grow at different temperatures was determined in GM-II medium and recorded after incubating the cultures for $20 \mathrm{~d}$ at 4 and $15^{\circ} \mathrm{C}$, and $2-7 \mathrm{~d}$ at $20-42^{\circ} \mathrm{C}$. The ability to grow in various $\mathrm{NaCl}$ concentrations was determined in GM-II medium containing $0-10 \%$ of $\mathrm{NaCl}$. Utilization of various compounds as sole carbon and energy sources for growth was determined in modified GM-II media containing $0 \cdot 2 \%(\mathrm{w} / \mathrm{v})$ of any one of the test substrates used in place of glucose. Nitrogen source utilization was also determined in GM-II medium and its modifications containing $\mathrm{KNO}_{3}$ at $20 \mathrm{mM}$ or any one of the test amino acids at $2 \mathrm{~g}^{-1}$ rather than $\mathrm{NH}_{4} \mathrm{Cl}$. All the test cultures were incubated at $25^{\circ} \mathrm{C}$ in the dark for $7 \mathrm{~d}$ under aerobic conditions unless stated otherwise.

Antibiotic susceptibility. Susceptibility to various antibiotics was determined with standard $6 \mathrm{~mm}$ discs (Difco). The discs were placed on PY plate medium that had been spread with broth culture $(0 \cdot 1 \mathrm{ml})$ of strain $\mathrm{FG}^{\mathrm{T}}$. Inhibition zones of growth around the discs were noted after incubating the plates at $25^{\circ} \mathrm{C}$ for $24-30 \mathrm{~h}$. They were interpreted as either susceptible or resistant with reference to standard data (NCCLS, 1990).

DNA base composition. This determination essentially followed the procedure described by Shieh \& Liu (1996).

Cellular fatty acids. Fatty acids in cells from early stationary phase cultures grown in GM-II medium were extracted, saponified and methylated according to Suutari et al. (1990). GLC analysis of the fatty acid methyl esters was performed on a GC-14A (Shimadzu) equipped with an FID and a fused silica capillary column (Shieh \& Jean, 1998).

Fermentation products. Strain $\mathrm{FG}^{\mathrm{T}}$ was anaerobically cultivated in GM-II medium under Ar. Cultures grown for 24-60 h were centrifuged to remove the cells. The supernatant samples, after filtering through a Nucleopore membrane (pore size, $0.22 \mu \mathrm{m}$ ), were analysed for organic acids produced during fermentative growth of the cultures by an HPLC equipped with an Interaction Ion-300 column (Shieh \& Jean, 1998). Production of $\mathrm{CO}_{2}$ and $\mathrm{H}_{2}$ gases in the headspace of the GM-II culture system was, meanwhile, detected by GC using a GC-14A equipped with a thermalconductivity detector and with either connected columns of Porapak Q and $\mathrm{N}$ (both $3 \mathrm{~mm} \times 2 \mathrm{~m}$; for $\mathrm{CO}_{2}$ analysis) or a column of molecular Sieve $5 \mathrm{~A}$ ( $3 \mathrm{~mm} \times 2 \mathrm{~m}$; for $\mathrm{H}_{2}$ analysis) at $70{ }^{\circ} \mathrm{C}$. Production of acetoin or butanediol in GM-II cultures was determined by the Voges-Proskauer reaction (Smibert \& Krieg, 1994)

$16 S$ rRNA gene sequencing and phylogenetic dendrogram construction. A method similar to that of Hiraishi (1992) was used for PCR amplification and sequencing of the $16 \mathrm{~S}$ rRNA gene of strain $F G 1^{T}$. The $16 \mathrm{~S}$ rDNA sequence was aligned manually with those of reference bacterial strains available in the GenBank database. The aligned positions from 33 to 1398 (by Escherichia coli sequence J01859 numbering) that were unambiguous and available for the sequences were used for the phylogenetic analysis. Distance matrices were calculated with the PHYLIP program DNADIST using the Jukes \& Cantor (1969) model by assuming a transition/transversion ratio of $2 \cdot 0$; a neighbour-joining phylogenetic dendrogram was then constructed according to the estimated evolutionary distances (Felsenstein, 1989).

Nucleotide sequence accession numbers. The accession numbers for the sequences used to construct the phylogenetic dendrogram are as follows: Vibrio aestuarianus ATCC $35048^{\mathrm{T}}$, X74689; Vibrio alginolyticus ATCC 17749 ${ }^{\mathrm{T}}$, X74690; Vibrio anguillarum ATCC $19264^{\mathrm{T}}$, X16895; Vibrio campbellii ATCC $25920^{\mathrm{T}}$, X74692; Vibrio carchariae ATCC $35084^{\mathrm{T}}$, X74693; Vibrio cholerae ATCC 14035 ${ }^{\mathrm{T}}$, X74695; Vibrio cincinnatiensis ATCC 35912 ${ }^{\mathrm{T}}$, X74698; Vibrio diabolicus $\mathrm{HE} 800^{\mathrm{T}}$, X99762; Vibrio diazotrophicus ATCC 33466 ${ }^{\mathrm{T}}$, X74701; Vibrio fischeri ATCC $7744^{\mathrm{T}}$, X74702; Vibrio fluvialis NCTC $11327^{\mathrm{T}}$, X76335; Vibrio furnissii ATCC $35016^{\mathrm{T}}$, X74704; Vibrio gazogenes ATCC 29988 ${ }^{\mathrm{T}}$, X74705; Vibrio halioticoli IAM $14596^{\mathrm{T}}$, X74690; Vibrio harveyi ATCC 14126 ${ }^{\mathrm{T}}$, X74706; Vibrio hollisae ATCC $33564^{\mathrm{T}}$, X74707; Vibrio logei ATCC 15832, X74708; Vibrio mediterranei CIP $103203^{\mathrm{T}}$, X74710; Vibrio metschnikovii NCTC 11170, X74712; Vibrio mimicus ATCC 33653 ${ }^{\mathrm{T}}$, X74713; Vibrio mytili CECT $632^{\mathrm{T}}$, X99761; Vibrio natriegens ATCC $14048^{\mathrm{T}}$, X74714; Vibrio navarrensis CIP 103381 ${ }^{\mathrm{T}}$, X74715; Vibrio nereis ATCC $25917^{\mathrm{T}}$, X74716; Vibrio nigripulchritudo ATCC 27043 ${ }^{\mathrm{T}}$, X74717; Vibrio ordalii ATCC $33509^{\mathrm{T}}$, 
X74718; Vibrio orientalis ATCC $33934^{\mathrm{T}}$, X74719; Vibrio parahaemolyticus ATCC $17802^{\mathrm{T}}$, X74720; Vibrio proteolyticus ATCC $15338^{\mathrm{T}}$, X74723; Vibrio salmonicida NCMB $2262^{\mathrm{T}}$, X70643; Vibrio scophthalmi CECT 4638 ${ }^{\mathrm{T}}$, U46579; Vibrio splendidus ATCC $33125^{\mathrm{T}}$, X74724; Vibrio tapetis CECT 4600 ${ }^{\mathrm{T}}$, Y08430; Vibrio tubiashii ATCC $19109^{\mathrm{T}}$, X74725; Vibrio vulnificus ATCC 27562 ${ }^{\mathrm{T}}$, X76333; Photobacterium histaminum JCM 8968 ${ }^{\mathrm{T}}$, D25308; Photobacterium iliopiscarium ATCC 51760 ${ }^{\mathrm{T}}$, AB000278; Photobacterium leiognathi ATCC $25521^{\mathrm{T}}$, X74686.

\section{RESULTS}

\section{Bacterial growth}

Strain $F G 1^{\mathrm{T}}$ grew over a $\mathrm{pH}$ range of $5 \cdot 0-8 \cdot 5$, with optimal growth at about $\mathrm{pH} 7 \cdot 0$. The strain grew significantly over a temperature range of $20-35^{\circ} \mathrm{C}$, and most rapidly at $30-35^{\circ} \mathrm{C}$. Growth was weak at 15 and $38{ }^{\circ} \mathrm{C}$, weak or negligible at $40^{\circ} \mathrm{C}$ and was not observed at all at 5 and $42{ }^{\circ} \mathrm{C}$. Both aerobic and anaerobic growth in GM-II medium were accompanied by a large decrease in medium $\mathrm{pH}$ (ca. $2 \mathrm{pH}$ units) during the exponential phase of growth (Fig. 1). Fig. 2 shows the effect of $\mathrm{NaCl}$ on growth. Strain $\mathrm{FG}^{\mathrm{T}}$ grew aerobically in GM-II medium containing 1-6\% $\mathrm{NaCl}$ (ca. 0.17-1.03 M); growth was most rapid at $4 \%$ $\mathrm{NaCl}($ ca. $0.68 \mathrm{M}$ ) and absent at $0 \%$. Substitution of $\mathrm{KCl}(2-5 \%)$ for $\mathrm{NaCl}$ did not support growth (not shown).

\section{Bacterial characterization}

Strain $\mathrm{FG}^{\mathrm{T}}$ was Gram-negative according to the staining and $\mathrm{KOH}$ testing methods. It produced flat, circular, off-white colonies on PY plate medium after 1-2 d incubation. Cells in late exponential to early stationary phase of growth in PY broth culture were

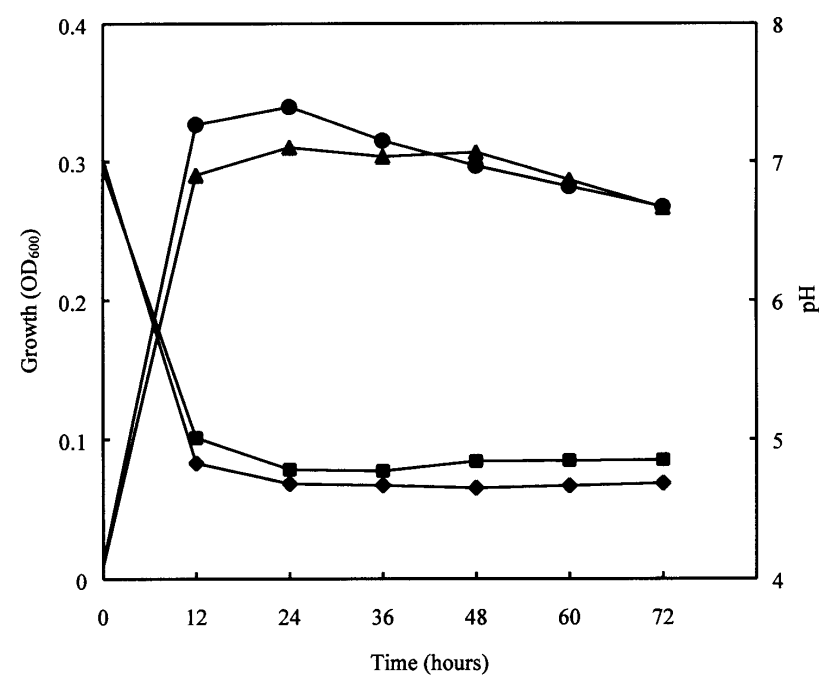

Fig. 1. Changes in $\mathrm{OD}_{600}$ and $\mathrm{pH}$ during aerobic and anaerobic growth of strain $\mathrm{FG} 1^{1}$ in $\mathrm{GM}-\mathrm{II}$ medium. $\boldsymbol{O}, \mathrm{OD}_{600}$ in aerobic culture; $\boldsymbol{\Delta}, \mathrm{OD}_{600}$ in anaerobic culture; $\diamond, \mathrm{pH}$ in aerobic culture; $\mathbf{\square}, \mathrm{pH}$ in anaerobic culture.

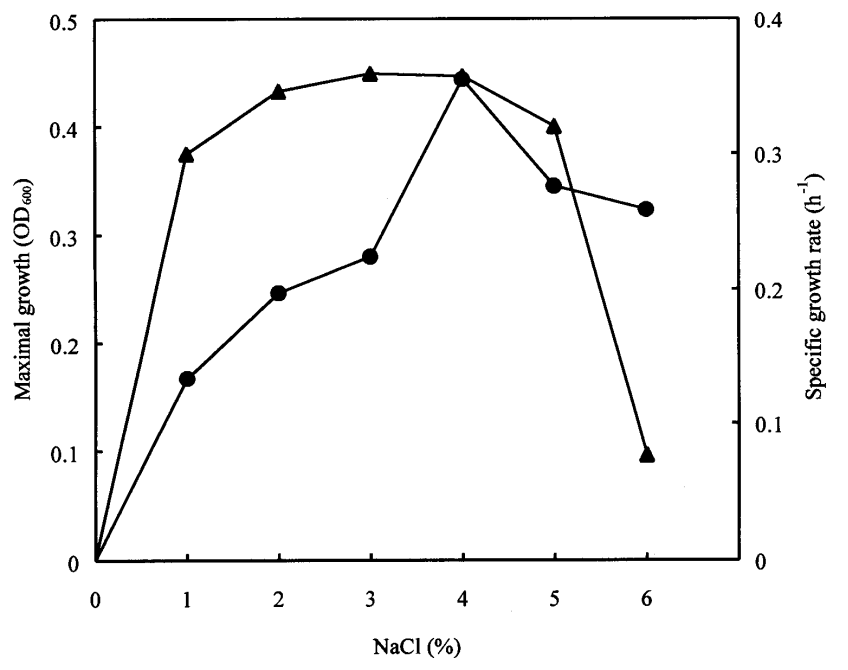

Fig. 2. Influence of $\mathrm{NaCl}$ concentration on aerobic growth of strain $\mathrm{FG}^{\top}$ in GM-II medium. $\boldsymbol{\bullet}$, Maximal growth; $\boldsymbol{\Delta}$, specific growth rate.

straight or slightly curved, motile rods that were $0 \cdot 6-0.8 \mu \mathrm{m}$ in diameter by $2-3 \mu \mathrm{m}$ in length. Electron microscopy revealed that they normally possessed two sheathed flagella at one pole of the cell (Fig. 3). Strain $\mathrm{FG}^{\mathrm{T}}$ was halophilic and unable to grow in the absence of $\mathrm{NaCl}$. It fermented glucose and other carbohydrates with production of gas. Catalase was positive but oxidase was negative. The strain did not accumulate any appreciable amount of PHB. It was not susceptible to the vibriostatic agent $\mathrm{O} / 129$ at $10-150 \mu \mathrm{g}$. Additional biochemical and physiological characteristics and the ability to utilize various compounds as sole carbon or nitrogen sources are given in the description of Vibrio aerogenes sp. nov. given below.

\section{Fermentation products}

Anaerobic fermentative growth of strain $\mathrm{FG}^{\mathrm{T}}$ in $\mathrm{GM}$ II medium resulted in formation of a variety of organic acids and the gases $\mathrm{CO}_{2}$ and $\mathrm{H}_{2}$. Acetate and lactate generally constituted more than $70 \mathrm{~mol} \%$ of the organic acid products. Other organic acids that have been detected included formate, malate, oxaloacetate, propionate, pyruvate and succinate. No evidence indicated the production of acetoin or butanediol in these fermentative cultures.

\section{Antibiotic susceptibility}

Strain $\mathrm{FG}^{\mathrm{T}}$ was susceptible to ampicillin, chloramphenicol, colistin, gentamicin, nalidixic acid, polymyxin B and streptomycin but resistant to the other test antibiotics (Table 1).

\section{Cellular fatty acids and DNA base composition}

Strain $\mathrm{FG}^{\mathrm{T}}$ contained $\mathrm{C} 12: 0$ as the most abundant cellular fatty acid $(50 \cdot 9-75 \cdot 3 \mathrm{~mol} \%)$. The other cellular fatty acids present at levels greater than $3 \mathrm{~mol} \%$ 

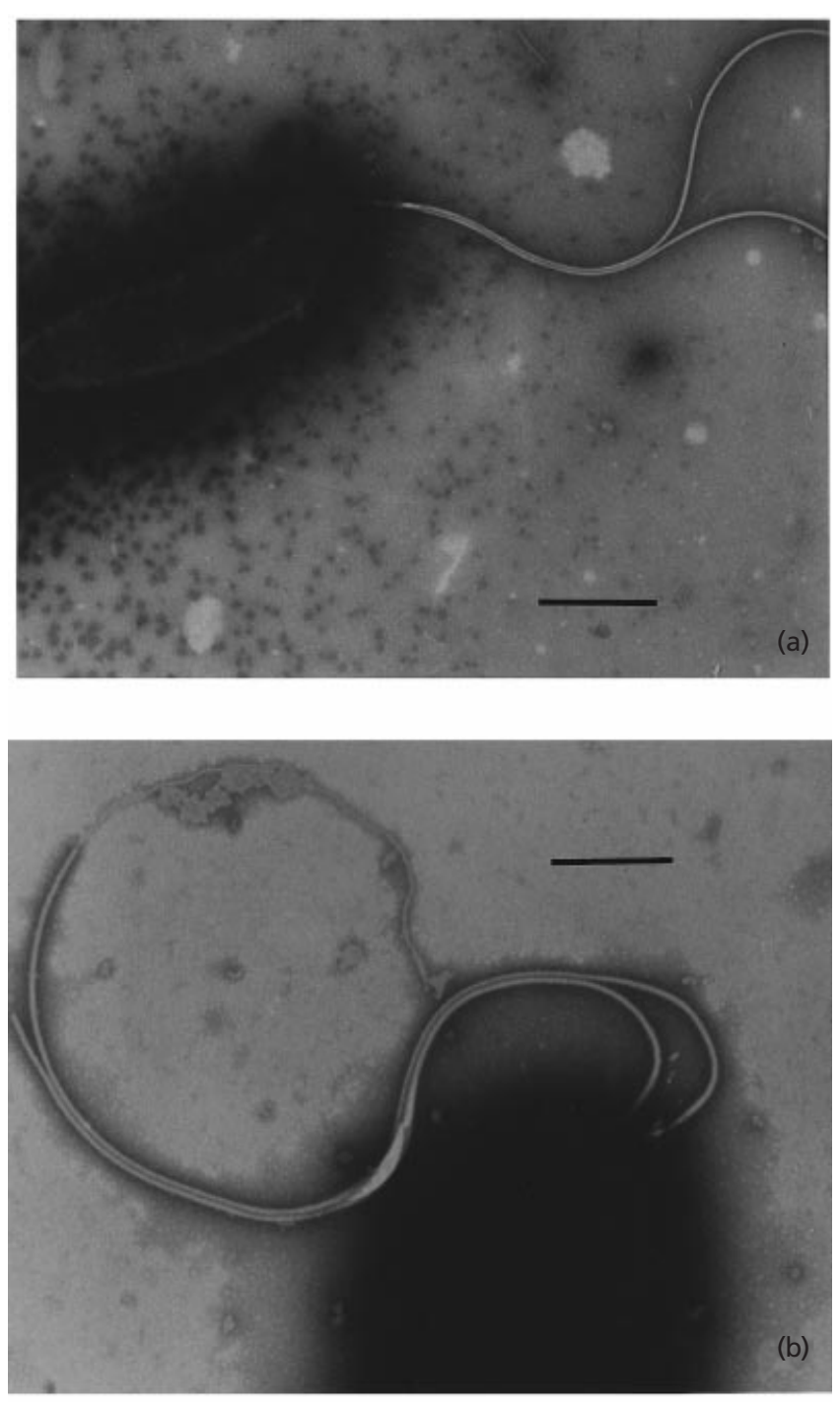

Fig. 3. (a) Electron micrograph of strain $\mathrm{FG}^{\top}$ showing two thick flagella at one pole of the rod-shaped cell. Scale bar, $1 \mu \mathrm{m}$. (b) Two sheathed polar flagella on one cell of strain $F G 1^{\top}$. One flagellum has lost the distal part of its sheath exposing the inner core. Scale bar, $0.5 \mu \mathrm{m}$.

included $\mathrm{C} 11: 0 \quad(4 \cdot 6-6 \cdot 2 \mathrm{~mol} \%), \quad \mathrm{C} 14: 0 \quad(6 \cdot 5-$ $14.6 \mathrm{~mol} \%)$, C16:0 (5.1-9.4 mol\%), iso-C16:0 (3.5$8 \cdot 2 \mathrm{~mol} \%)$ and $\mathrm{C} 18: 1^{\Delta 9}(7 \cdot 0-10 \cdot 6 \mathrm{~mol} \%)$.

Strain $\mathrm{FG}^{\mathrm{T}}$ had a $\mathrm{G}+\mathrm{C}$ content of $45 \cdot 9 \mathrm{~mol} \%$.

\section{S rDNA-based phylogenetic analysis}

An almost complete 16S rDNA sequence (ca. 89\%; estimated by comparison with the E. coli sequence J01859) of strain FG1 ${ }^{\mathrm{T}}$ was obtained. Phylogenetic analysis based on the $16 \mathrm{~S}$ rDNA sequence comparisons showed that the strain is a member of the genus Vibrio in the gamma subclass of the Proteobacteria. The dendrogram in Fig. 4 shows the phylogenetic position of strain $\mathrm{FGl}^{\mathrm{T}}$ within the radiation of the
Table 1. Susceptibility of strain $\mathrm{FG} 1^{\top}$ to various antibiotics

\begin{tabular}{|lccc|}
\hline Antibiotic & $\begin{array}{c}\text { Disc } \\
\text { content }\end{array}$ & $\begin{array}{c}\text { Inhibition zone } \\
\text { diameter (mm) }\end{array}$ & Reaction* \\
\hline Ampicillin & $10 \mu \mathrm{g}$ & 25 & $\mathrm{~S}$ \\
Chloramphenicol & $30 \mu \mathrm{g}$ & 30 & $\mathrm{~S}$ \\
Clindamicin & $2 \mu \mathrm{g}$ & 6 & $\mathrm{R}$ \\
Colistin & $10 \mu \mathrm{g}$ & 20 & $\mathrm{~S}$ \\
Erythromycin & $15 \mu \mathrm{g}$ & 12 & $\mathrm{R}$ \\
Gentamicin & $10 \mu \mathrm{g}$ & 24 & $\mathrm{~S}$ \\
Kanamycin & $30 \mu \mathrm{g}$ & 13 & $\mathrm{R}$ \\
Lincomycin & $5 \mu \mathrm{g}$ & 6 & $\mathrm{R}$ \\
Nalidixic acid & $30 \mu \mathrm{g}$ & 20 & $\mathrm{~S}$ \\
Novobiocin & $30 \mu \mathrm{g}$ & 12 & $\mathrm{R}$ \\
Penicillin G & $10 \mathrm{U}$ & 15 & $\mathrm{R}$ \\
Polymyxin B & $300 \mathrm{U}$ & 20 & $\mathrm{~S}$ \\
Streptomycin & $10 \mu \mathrm{g}$ & $18 \cdot 5$ & $\mathrm{~S}$ \\
Tetracycline & $30 \mu \mathrm{g}$ & 12 & $\mathrm{R}$ \\
\hline
\end{tabular}

* S, susceptible; $\mathrm{R}$, resistant.

genus Vibrio and some related bacteria. The levels of 16S rDNA sequence similarity between strain $\mathrm{FG}^{\mathrm{T}}$ and the known Vibrio species were never greater than $96.2 \%$ (not shown); the highest similarity level found $(96.2 \%)$ was observed with $V$. mytili.

\section{DISCUSSION}

The mesophilic strain $\mathrm{FG}^{\mathrm{T}}$ could be categorized as a slightly halophilic bacterium (Kushner \& Kamekura, 1988) since it required $\mathrm{NaCl}$ for growth with optimum growth at $4.0 \%$ (ca. $0.51-0.68 \mathrm{M}$ ). The requirement for $\mathrm{NaCl}$ could not be substituted by $\mathrm{KCl}$, indicating that the strain required $\mathrm{Na}^{+}$and not $\mathrm{Cl}^{-}$for growth and it also showed that the $\mathrm{Na}^{+}$requirement was not for osmotic function.

Strain $\mathrm{FG}^{\mathrm{T}}$ grew significantly in GM-II medium under both aerobic and anaerobic conditions, which indicated that the strain is a facultative anaerobe and does not require vitamins or other organic growth factors. The anaerobic growth in GM-II medium was accompanied by a remarkable decrease in medium $\mathrm{pH}$ (ca. $2 \mathrm{pH}$ units) during the exponential phase of growth, regardless of the large buffer content $(25 \mathrm{mM}$ MOPSO) in the medium. This indicated that the strain achieved anaerobic growth in the medium by fermenting glucose with the production of considerable amounts of acids. Detection of various organic acids including acetate, lactate, succinate, formate, malate, oxaloacetate, propionate and succinate from the anaerobic GM-II cultures further indicated that strain $\mathrm{FG}^{\mathrm{T}}$ is a mixed acid fermenter. Similar acidification occurring in the aerobic GM-II cultures during bacterial growth was possibly due to the creation of an oxygen-depleted microenvironment in such static cultures. 


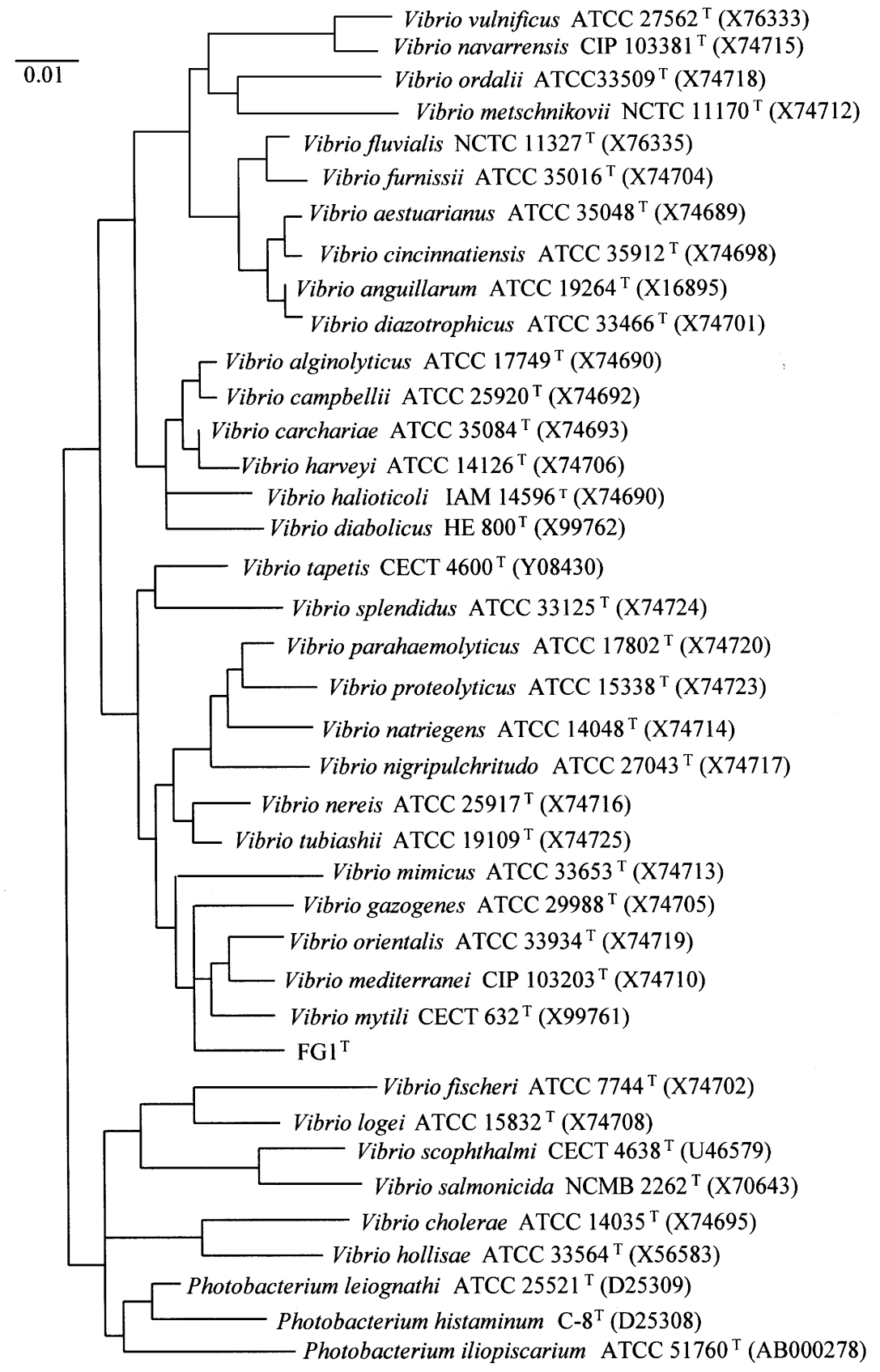

Fig. 4. $16 \mathrm{~S}$ rDNA-based phylogenetic dendrogram showing the position of strain $\mathrm{FG} 1^{\top}$ within the radiation of the Vibrio species and some reference bacteria. Scale bar, evolutionary distance $\left(K_{\text {nuc }}\right)$ of 0.01 .

Strain $F G 1^{T}$ is characterized as a mesophilic, slightly halophilic, facultatively anaerobic, Gram-negative rod that is motile by sheathed polar flagella and unable to accumulate $\mathrm{PHB}$, indicating that the strain is probably a species of Vibrio in the family Vibrionaceae (Baumann \& Schubert, 1984; Baumann et al., 1984). A 16S rDNA-based phylogenetic analysis has revealed that the sequence of strain $\mathrm{FG}^{\mathrm{T}}$ indeed falls inside the cluster made up of the representative sequences of the known Vibrio species (Fig. 4). Data analysis also supports the establishment of a new species since the levels of $16 \mathrm{~S}$ rDNA sequence similarity between strain $\mathrm{FG}^{\mathrm{T}}$ and all known species of Vibrio are never greater than $96.2 \%$. Thus, the name Vibrio aerogenes is proposed for this new bacterium. $V$. aerogenes possesses some phenotypic characteristics quite uncommon among the vibrios, including production of gas from glucose, two polar flagella on each cell, resistance to $\mathrm{O} / 129$ and a negative oxidase reaction (Holt et al., 1994). V. gazogenes and V. metschnikovii are the only two Vibrio species previously reported to be negative for the oxidase reaction. Only the former produces gas from glucose. However, V. gazogenes is not resistant to $\mathrm{O} / 129$ and has only single polar flagellum on each cell (Baumann et al., 1984; Harwood, 1978). Moreover, it produces red to orange colonies on plate media. Colonies produced by $V$. aerogenes, on the other hand, are off-white. More detailed characteristics useful for 
Table 2. Phenotypic characteristics useful for differentiating Vibrio aerogenes $\mathrm{FG} 1^{\top}$ from previously described oxidase-negative and/or gas-producing species in the family Vibrionaceae

Data from this study and previous studies (Baumann \& Baumann, 1984; Baumann et al., 1984; Brenner et al., 1983; Harwood, 1978; Holt et al., 1994; Okuzumi et al., 1994; Pujalte et al., 1993; Urakawa et al., 1999). Strains: 1, Vibrio aerogenes $\mathrm{FGl}^{\mathrm{T}}$; 2, Vibrio furnissii; 3, Vibrio gazogenes; 4, Vibrio mytili; 5, Vibrio metschnikovii; 6, Photobacterium histaminum; 7, Photobacterium iliopiscarium; 8, Photobacterium phosphoreum; 9, Photobacterium damselae subsp. damselae (formerly Listonella damsela). + , Positive; - , negative; v, variable; ND, no data available.

\begin{tabular}{|c|c|c|c|c|c|c|c|c|c|}
\hline Characteristic & 1 & 2 & 3 & 4 & 5 & 6 & 7 & 8 & 9 \\
\hline Gas from glucose & + & + & + & + & - & + & + & + & + \\
\hline Oxidase & - & + & - & + & - & + & ND & ND & + \\
\hline $\mathrm{O} / 129$ sensitivity $(150 \mu \mathrm{g})$ & - & + & + & + & + & + & + & ND & + \\
\hline Red-orange pigment & - & - & + & - & - & - & - & - & - \\
\hline PHB accumulation & - & ND & - & ND & - & + & + & + & ND \\
\hline Nitrate reduction & + & + & - & + & - & + & + & + & + \\
\hline Sheathed polar flagella & + & + & + & ND & + & - & - & - & + \\
\hline Amylase & + & ND & + & - & + & + & ND & - & $\mathrm{V}$ \\
\hline Gelatinase & + & + & + & - & + & - & - & - & - \\
\hline Lipase & + & + & + & ND & + & ND & ND & - & - \\
\hline Arginine dihydrolase & + & + & - & + & - & ND & + & ND & + \\
\hline \multicolumn{10}{|l|}{ Growth at: } \\
\hline $4{ }^{\circ} \mathrm{C}$ & - & - & - & - & - & - & + & + & - \\
\hline $35^{\circ} \mathrm{C}$ & + & + & + & + & + & + & - & - & + \\
\hline Growth in $10 \% \mathrm{NaCl}$ & - & + & - & + & - & - & - & ND & - \\
\hline \multicolumn{10}{|l|}{ Utilization of: } \\
\hline Cellobiose & + & - & + & + & - & + & - & - & - \\
\hline Sucrose & + & + & + & + & + & - & - & - & - \\
\hline Mannose & + & + & + & - & $\mathrm{V}$ & + & + & + & + \\
\hline Xylose & + & - & + & + & - & - & - & - & - \\
\hline Mannitol & + & + & + & + & + & - & - & - & - \\
\hline Inositol & + & - & - & - & $\mathrm{V}$ & ND & - & - & - \\
\hline Citrate & + & + & + & $\mathrm{V}$ & $\mathrm{V}$ & - & - & - & - \\
\hline
\end{tabular}

differentiating $V$. aerogenes from $V$. gazogenes and other oxidase-negative or gas-producing species in the family Vibrionaceae are listed in Table 2.

$V$. aerogenes is presently found only in the marine sediment. However, the requirement for $\mathrm{NaCl}$ and a moderate temperature indicates that this species may also occur in shallow coastal and oceanic seawaters.

\section{Description of Vibrio aerogenes sp. nov.}

Vibrio aerogenes (a.e.ro'ge.nes. Gr. masc. n. aer air; Gr. v. gennanio to produce; M.L. adj. aerogenes gasproducing).

Straight to slightly curved rod. Cells stain Gramnegative and are $0.6-0.8 \mu \mathrm{m}$ wide by $2-3 \mu \mathrm{m}$ long. Swarming does not occur on solid agar media while motility normally occurs by means of two sheathed, polar flagella when grown in liquid media. Colonies produced on agar media are flat, circular, off-white and non-luminescent with an entire margin. The species is a facultative anaerobe capable of both aerobic and anaerobic fermentative growth. Acid and gas are produced from fermentation of glucose and other carbohydrates such as cellobiose, galactose, inositol, mannitol, mannose, sucrose and xylose. However, Darabinose, dulcitol, lactose, sorbitol and trehalose are not fermented. Voges-Proskauer reaction is negative. Accumulation of PHB inside the cells is not observed. Catalase, arginine dihydrolase, amylase, caseinase, DNase, gelatinase and lipase are positive while oxidase, agarase, and lysine and ornithine decarboxylases are negative. Indole is produced. Nitrate is reduced to nitrite but not further to $\mathrm{N}_{2} \mathrm{O}$ or $\mathrm{N}_{2}$. The species is mesophilic, growing well at $20-35^{\circ} \mathrm{C}$ but not at all at 4 or $42{ }^{\circ} \mathrm{C}$. It is able to grow in a mineral medium containing glucose and ammonium or nitrate salts. It grows at $\mathrm{NaCl}$ levels of $1-7 \%$ with optimal growth at about $4 \%$ while no growth occurs at 0 and $10 \% \mathrm{NaCl}$. It is resistant to the vibriostatic agent $\mathrm{O} / 129$ (10 or $150 \mu \mathrm{g}$ per disc). The most abundant cellular fatty acid is C12:0. The following compounds are utilized as sole carbon and energy sources: cellobiose, galactose, glucose, sucrose, mannose, xylose, citrate, fumarate, pyruvate, inositol, mannitol, L-alanine, L-aspartate, Lglutamate and L-threonine. The following compounds 
are not utilized as sole carbon and energy sources: Darabinose, lactose, melibiose, trehalose, acetate, $\beta$ hydroxybutyrate, DL-malate, malonate, tartrate, adonitol, dulcitol, sorbitol, L-arginine, L-glycine, L-lysine, L-methionine, L-ornithine, L-phenylalanine, L-tryptophan and L-valine. The species utilizes ammonium, nitrate and the L-form amino acids alanine, arginine, aspartate, glutamate, lysine, methionine, ornithine, phenylalanine, threonine, tryptophan and valine as sole nitrogen sources for growth. The DNA $\mathrm{G}+\mathrm{C}$ composition is about $46 \cdot 0 \mathrm{~mol} \%$. The species is found in coastal sediment. The type strain is $\mathrm{FG}^{\mathrm{T}}$, which has been deposited in the American Type Culture Collection as strain ATCC $700797^{\mathrm{T}}$ and in the Culture Center for Research and Collection, Taiwan as strain CCRC $17041^{\mathrm{T}}$.

\section{ACKNOWLEDGEMENTS}

This work was supported by the National Science Council under the grant number NSC88-2311-B-002-048. Thanks are due to Dr J.-S. Chen for critical reading of the manuscript.

\section{REFERENCES}

Baumann, P. \& Baumann, L. (1971). Taxonomy of marine bacteria: the genus Beneckea. J Bacteriol 107, 268-294.

Baumann, P. \& Baumann, L. (1984). Genus II Photobacterium Beijerinck 1889, 401 ${ }^{\mathrm{AL}}$. In Bergey's Manual Systematic Bacteriology, vol. 1, pp. 516-550. Edited by N. R. Krieg \& J. G. Holt. Baltimore: Williams \& Wilkins.

Baumann, P. \& Schubert, R. H. W. (1984). Family II Vibrionaceae Veron 1965, 5245 ${ }^{\mathrm{AL}}$. In Bergey's Manual Systematic Bacteriology, vol. 1, pp. 516-517. Edited by N. R. Krieg \& J. G. Holt. Baltimore: Williams \& Wilkins.

Baumann, P., Furniss, A. L. \& Lee, J. V. (1984). Genus I Vibrio Pacini 1854, $411^{\mathrm{AL}}$. In Bergey's Manual Systematic Bacteriology, vol. 1, pp. 518-538. Edited by N. R. Krieg \& J. G. Holt. Baltimore: Williams \& Wilkins.

Blake, P. A., Weaver, R. E. \& Hollis, D. G. (1980). Disease of humans (other than cholera) caused by vibrios. Annu Rev Microbiol 34, 341-367.

Brenner, D. J. (1984). Family I. Enterobacteriaceae Rahn 1937, Nom. fam. Cons. Opin. 15, Jud. Comm. 1958, 73; Ewing, Farmer, and Brenner 1980, 674; Judicial Commission 1981, 104. In Bergey's Manual Systematic Bacteriology, vol. 1, pp. 518-538. Edited by N. R. Krieg \& J. G. Holt. Baltimore: Williams \& Wilkins.

Brenner, D. J., Hickman-Brenner, F. W., Lee, J. V. \& 7 other authors (1983). Vibrio furnissii (formerly aerogenic biogroup of Vibrio fluvialis), a new species isolated from human feces and the environment. J Clin Microbiol 18, 816-824.

Buck, J. D. (1982). Nonstaining $(\mathrm{KOH})$ method for determination of Gram reactions of marine bacteria. Appl Environ Microbiol 44, 992-993.

Cerdà-Cuéllar, M., Rosselló-Mora, R. A., Lalucat, J., Jofre, J. \& Blanch, A. (1997). Vibrio scophthalmi sp. nov., a new species from turbot (Scophthalmus maximus). Int J Syst Bacteriol 47, 58-61.

Collins, C. H., Lyne, P. M. \& Grange, J. M. (editors) (1995). Chapter 7. Identification Methods. In Collins and Lyne's
Microbiological Methods, 7th edn, pp. 102-120. London: Butterworth-Heinemann.

Colwell, R. R., MacDonell, M. T. \& De Ley, J. (1986). Proposal to recognize the family Aeromonadaceae fam. nov. Int $J$ Syst Bacteriol 36, 473-477.

Deming, J. W., Somers, L. K., Straube, W. L., Swartz, D. G. \& MacDonell, M. T. (1988). Isolation of an obligately barophilic bacterium and description of a new genus, Colwellia gen. nov. Syst Appl Microbiol 10, 152-160.

Egidus, E., Wilk, R., Andersen, K., Hoff, K. A. \& Hjelnes, B. (1986). Vibrio salmonicida sp. nov., a new fish pathogen. Int $J$ Syst Bacteriol 36, 518-520.

Felsenstein, J. (1989). PHYLIP - phylogeny inference package. Cladistics 5, 164-166.

Guerinot, M. L. \& Colwell, R. R. (1985). Enumeration, isolation, and characterization of $\mathrm{N}_{2}$-fixing bacteria from seawater. Appl Environ Microbiol 50, 350-355.

Guerinot, M. L., West, P. A., Lee, J. V. \& Colwell, R. R. (1982). Vibrio diazotrophicus sp. nov., a marine nitrogen-fixing bacterium. Int J Syst Bacteriol 32, 350-357.

Hada, H. S., West, P. A., Lee, J. V., Stemmler, J. \& Colwell, R. R. (1984). Vibrio tubiashii sp. nov., a pathogen of bivalve mollusks. Int J Syst Bacteriol 34, 1-4.

Harwood, C. S. (1978). Beneckea gazogenes sp. nov., a red, facultatively anaerobic, marine bacterium. Curr Microbiol 1, 233-238.

Hiraishi, A. (1992). Direct automatic sequencing of 16S rDNA amplified by polymerase chain reaction from bacterial cultures without DNA purification. Lett Appl Microbiol 15, 210-213.

Holt, J. G., Krieg, N. R., Sneath, P. H., Staley, J. T. \& Williams, S. T. (editors) (1994). Group 5 facultatively anaerobic Gram-negative rods. Subgroup 2: family Vibrionaceae. In Bergey's Manual of Determinative Bacteriology, 9th edn, pp. 190-194. Baltimore: Williams \& Wilkins.

Jukes, T. H. \& Cantor, C. R. (1969). Evolution of protein molecules. In Mammalian Protein Metabolism, pp. 21-132. Edited by H. N. Munro. New York: Academic Press.

Kushner, D. J. \& Kamekura, M. (1988). Physiology of halophilic eubacteria. In Halophilic Bacteria, vol. 1, pp. 109-138. Edited by F. Rodriguez-Valera. Boca Raton, FL: CRC Press.

Lee, K. H. \& Ruby, E. G. (1994). Competition between Vibrio fischeri strains during initiation and maintenance of a light organ symbiosis. J Bacteriol 176, 1985-1991.

Leisman, G., Cohn, D. H. \& Nealson, K. H. (1980). Bacterial origin of luminescence in marine animals. Science 208, 1271-1273.

Liston, J. (1956). Quantitative variations in the bacterial flora of flat fish. J Gen Microbiol 15, 305-314.

Love, M., Teebken-Fisher, D., Hose, J. E., Hickman, F. W. \& Fanning, G. R. (1981). Vibrio damsela, a marine bacterium, causes skin ulcers on the damselfish Chromis punctipinnis. Science 214, 1139-1140.

MacDonald, N. L., Stark, J. R. \& Austin, B. (1986). Bacterial microflora in the gastro-intestinal tract of Dover sole (Solea solea $\mathrm{L}$.), with emphasis on the possible role of bacteria in the nutrition of the host. FEMS Microbiol Lett 35, 107-111.

MacDonell, M. T. \& Colwell, R. R. (1985). The phylogeny of the Vibrionaceae and recommendation for two new genera, Listonella and Shewanella. Syst Appl Microbiol 6, 171-182.

McFall-Ngai, M. J. \& Ruby, E. G. (1991). Symbiont recognition and subsequent morphogenesis as early events in an animalbacterial mutualism. Science 254, 1491-1494. 
Nair, S., Kita-Tsukamoto, K. \& Simidu, U. (1988). Bacterial flora of healthy and abnormal chaetognaths. Nippon Suisan Gakkaishi 54, 491-496.

NCCLS (1990). Performance Standards for Antimicrobial Disk Susceptibility Tests, 4th edn, Approved Standard M2-A4. Villanova, PA: National Committee for Clinical Laboratory Standards.

Okuzumi, M., Hiraishi, A., Kobayashi, T. \& Fujii, T. (1994). Photobacterium histaminum sp. nov., a histamine-producing marine bacterium. Int J Syst Bacteriol 44, 631-636.

Onarheim, A. M., Wiik, R., Burghardt, J. \& Stackebrandt, E. (1994). Characterization and identification of two Vibrio species indigenous to the intestine of fish in cold sea water; description of Vibrio iliopiscarius sp. nov. Syst Appl Microbiol 17, 370-379.

Pujalte, M. J., Ortigosa, M., Urdaci, M.-C., Garay, E. \& Grimont, P. A. D. (1993). Vibrio mytili sp. nov., from mussels. Int J Syst Bacteriol 43, 358-362.

Reichelt, J. L., Nealson, K. H. \& Hastings, J. W. (1977). The specificity of symbiosis: pony fish and luminescent bacteria. Arch Microbiol 112, 157-161.

Ruby, E. G. \& Asato, L. M. (1993). Growth and flagellation of Vibrio fischeri during initiation of the sepiolid squid light organ symbiosis. Arch Microbiol 159, 160-167.

Ruby, E. G. \& Morin, J. G. (1978). Specificity of symbiosis between deep-sea fishes and psychrotrophic luminous bacteria. Deep Sea Res 25, 161-167.

Shieh, W. Y. \& Jean, W. D. (1998). Alterococcus agarolyticus gen. nov., sp. nov., a halophilic thermophilic bacterium capable of agar degradation. Can J Microbiol 44, 567-575.

Shieh, W. Y. \& Lin, Y. M. (1992). Nitrogen fixation (acetylene reduction) associated with the zoanthid Palythoa tuberculosa Esper. J Exp Mar Biol Ecol 163, 31-41.

Shieh, W. Y. \& Lin, Y. M. (1994). Association of heterotrophic nitrogen-fixing bacteria with a marine sponge of Halichondria sp. Bull Mar Sci 54, 557-564.

Shieh, W. Y. \& Liu, C. M. (1996). Denitrification by a novel halophilic fermentative bacterium. Can J Microbiol 42, 507-514.

Shieh, W. Y. \& Yang, J. T. (1997). Denitrification in the rhizosphere of the two seagrass Thalassia hemprichii (Ehrenb.) and Halodule uninervis (Forsk.) Aschers. J Exp Mar Biol Ecol 218, 229-241.
Shieh, W. Y., Simidu, U. \& Maruyama, Y. (1989). Enumeration and characterization of nitrogen-fixing bacteria in an eelgrass (Zostera marina) bed. Microb Ecol 18, 249-259.

Shieh, W. Y., Simidu, U. \& Maruyama, Y. (1990). A Photobacterium-like bacterium able to fix nitrogen. Antonie Leeuwenhoek 57, 51-54.

Schiewe, M. H., Trust, T. J. \& Crosa, J. H. (1981). Vibrio ordalii sp. nov. - a causative agent of vibriosis in fish. Curr Microbiol 6, 346-348.

Simidu, U. \& Tsukamoto, K. (1985). Habitat segregation and biochemical activities of marine members of the family Vibrionaceae. Appl Environ Microbiol 50, 781-790.

Simidu, U., Kaneko, E. \& Aiso, K. (1969). Microflora of fresh and stored flat-fish (Kareus bicoloratus). Bull Jpn Soc Sci Fish 35, 77-82.

Simidu, U., Ashino, K. \& Kaneko, E. (1971). Bacterial flora of phyto- and zoo-plankton in the inshore water of Japan. Can J Microbiol 17, 1157-1160.

Smibert, R. M. \& Krieg, N. R. (1994). Systematics: phenotypic characterization. In Manual of Methods for General and Molecular Bacteriology, pp. 607-654. Edited by P. Gerhardt. Washington, DC: American Society for Microbiology.

Sochard, M. R., Wilson, D. F., Austin, B. \& Colwell, R. R. (1979). Bacteria associated with the surface and gut of marine copepods. Appl Environ Microbiol 37, 750-759.

Suutari, M., Liukkonen, K. \& Laakso, S. (1990). Temperature adaptation in yeasts: the role of fatty acids. J Gen Microbiol 136, 1469-1474.

Urakawa, H., Kita-Tsukamoto, K. \& Ohwada, K. (1999). Reassessment of the taxonomic position of Vibrio iliopiscarius (Onarheim et al. 1994) and proposal for Photobacterium iliopiscarium comb. nov. Int J Syst Bacteriol 49, 257-260.

West, P. A., Brayton, P. R., Twilley, R. R., Bryant, T. N. \& Colwell, R. R. (1985). Numerical taxonomy of nitrogen-fixing 'decarboxylase-negative' Vibrio species isolated from aquatic environments. Int J Syst Bacteriol 35, 198-205.

Yoshimizu, M., Kimura, T. \& Sakai, M. (1976). Studies on the intestinal microflora of Salmonids. III. The intestinal microflora of salmon living in the open sea. Bull Jpn Soc Sci Fish 42, $875-884$. 